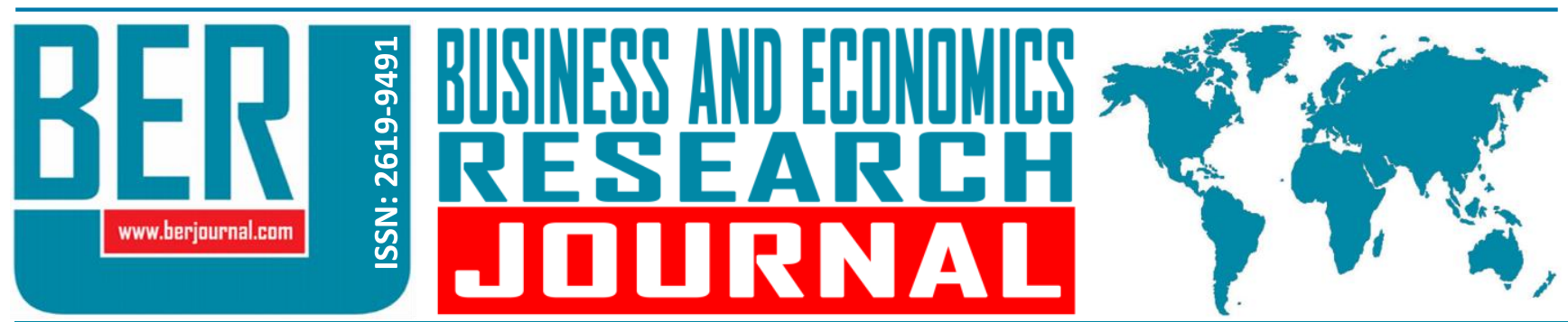

Business and Economics Research Journal Vol. 9, No. 4, 2018, pp. 901-909 doi: 10.20409/berj.2018.146

\title{
Girişimcilik Eğilimlerinin Demografik Değişkenler Açısından İncelenmesi
}

\begin{abstract}
Ayhan Yalcinsoy ${ }^{\mathrm{a}}$, Cenk Aksoy ${ }^{\mathrm{b}}$
Öz: Araştırma, bir kamu üniversitesinde eğitim gören öğrenciler üzerinde yapılmıştır. Araştırmada öğrencilerin girişimcilik eğilimleri demografik değişkenler açısından incelenmiştir. Araştırmada kullanılan veriler anket yöntemi ile elde edilmiştir. 2299 öğrencinin katılımıyla elde edilen veriler SPSS 18.0 istatistik uygulaması ile t-testi, ANOVA ve frekans analizlerine tabi tutulmuştur. Yapılan analiz sonucunda; eğitim durumu, yaş ve cinsiyet ile girişimcilik eğilimleri arasında anlamlı ilişkiler tespit edilmiştir. Eğitim durumu ile girişimcilik eğilimleri arasında anlamlı bir farklılık bulunduğu, ön lisans ve yüksek lisans öğrencilerinin girişimcilik eğilimlerinin diğerlerine göre daha yüksek olduğu tespit edilmiştir. Öğrencilerin yaşları ile girişimcilik eğilimleri arasında anlamlı bir farklılı olduğu, 20-24 yaş grubunda olanların girişimcilik eğilimlerinin diğer yaş grubunda olanların girişimcilik eğilimlerinden daha yüksek olduğu tespit edilmiştir. Ayrıca, öğrencilerin cinsiyetleri ile girişimcilik eğilimlerin arasında anlamlı bir farklılık olduğu, erkeklerin girişimcilik eğilimlerinin kadınların girişimcilik eğilimlerinden daha yüksek olduğu sonucuna varılmıştır. Demografik değişkenlerden gelir durumu ve öğrencinin sınıfı ile girişimcilik eğilimleri arasında anlamlı bir ilişk tespit edilmemiştir.
\end{abstract}

\section{An Investigation of the Entrepreneurial Tendency in terms of Demographic Variables}

\begin{abstract}
The research was conducted on students studying at a public university. The entrepreneurial tendencies of the students in the survey were examined in terms of demographic variables. The data used in the research were obtained by questionnaire method. The data obtained with the participation of 2299 students were subjected to t-test, ANOVA and frequency analyzes with SPSS 18.0 statistical program. As a result of the analysis; significant relationships were found between educational status, age, gender, and entrepreneurial tendencies. It was found that there was a significant difference between educational status and entrepreneurial tendencies that entrepreneurial tendencies of associate and graduate students were higher than others. It was found that there was a significant difference between the age of students and entrepreneurship trends that entrepreneurial tendencies of those aged between 20-24 years were found to be higher than those of the other age groups. Moreover, there is a significant difference between students' genders and entrepreneurial tendencies that men's entrepreneurial tendencies are higher than women's entrepreneurial tendencies. There was no significant relationship between the income status of the demographic variables and the class of the student and entrepreneurial tendencies.
\end{abstract}

Anahtar Sözcükler: Girişimcilik, Girişimcilik Eğilimleri, Üniversite, Demografik Değişkenler

JEL: L26, J13

$\begin{array}{ll}\text { Geliş } & : 24 \text { Nisan } 2018 \\ \begin{array}{l}\text { Düzeltme } \\ \text { Kabul }\end{array} & : 18 \text { Haziran } 2018 \\ & : \text { 13 Ağustos } 2018 \\ \text { Tür } & : \text { Araştırma }\end{array}$

Keywords: Entrepreneurship, Entrepreneurial Tendencies, University, Demographic Variables

JEL: L26, J13

$\begin{array}{ll}\text { Received } & : 24 \text { April } 2018 \\ \text { Revised } & : \text { 18 June } 2018 \\ \text { Accepted } & : \text { 13 August } 2018 \\ & \\ \text { Type } & : \text { Research }\end{array}$

a PhD., Dicle University, Institute of Social Sciences, Diyarbakir, Turkiye, ayhanyalcinsoy@gmail.com (ORCID ID: 0000-0002-0510-1586)

b Res. Asst., Dicle University, School of Civil Aviation, Department of Aviation Management, Diyarbakir, Turkiye, drcenkaksoy@gmail.com (ORCID ID: 0000-0003-0763-2847) 


\section{Giriş}

Genellikle ekonomik açıdan ele alınan girişimcilik aslında bireylerin veya toplumların karakteristik bir özelliğidir. Girişimcilik, bireylerin doğuştan gelen bir özelliği olarak da değerlendirilebilir. Çevredeki pazar fırsatlarını görebilme, yeni pazarlama ve satış teknikleri geliştirme, ekonomik değere dönüştürülebilen yenilikçi bakış açısına sahip olma, problemler karşısında hızlı ve optimum çözümler üretebilme doğuştan gelen özelliklerdir. Sonradan bu özelliklerden bazıları kazanılsa bile doğuştan bu özelliklere sahip olanlara göre yeterli olamamaktadır.

Karakteristik özelliklerin yanı sıra girişimcilik bir bakış açısı olarak da görülebilir. Gelişen teknoloji ile birlikte ortaya çıkan yenilikleri ekonomide meydana gelen gelişmelerle birleştirerek yeni stratejiler ortaya konulması, yeni yönetim anlayışlarının geliştirilmesi, yenilikçiliğin kurumun kurumsal bir parçası haline getirilmesi, rekabet avantajını artırmak için farklılık oluşturulması, sorun odaklı yerine çözüm odaklı bir yönetim anlayışına sahip olunması, teknolojik değişimlerin iyi takip edilerek eş güdümlü bir şekilde yeni ürün, hizmet ve bakış açısı geliştirilmesi günümüz işletmeciliği için önemli kriterlerdir.

Günümüz işletmecilik anlayışı ve sert rekabet koşulları dikkate alındığında girişimcilik faaliyetlerinin önemi daha iyi anlaşılmaktadır. Rekabet koşullarının ağır olduğu küresel pazarlarda yer bulabilmek, tutunabilmek ve küresel bir işletme olabilmek vizyon sahibi, yenilikçi ve farklı düşünebilen girişimcilerle mümkün olacaktır.

Araştırma, KOSGEB tarafından yatırım açısından öncelikli olarak en çok desteklenen 6.bölgede olan ve cazibe merkezleri programı kapsamındaki iller arasında yer alan Diyarbakır ilinde gerçekleştirilmiştir (KOSGEB, 2018). Diyarbakır, sanayi alanında uzun yıllar eğitimsizlik, terör ve genel ekonomiden kaynaklanan istikrarsılıklar nedeniyle potansiyelini değerlendirememiş ve gelişme bakımından olması gereken düzeyin çok gerisinde kalmış bir ilimizdir. Gerek genç nüfusu ve dinamizmi ile gerekse yerüstü ve yeraltı kaynaklarının zenginliğiyle ayrıca da coğrafik olarak Ortadoğu'da yeni gelişen pazarlara yakınlığı dolayısıyla gelişmeye yönelik birçok potansiyel avantajlara sahiptir.

Yapılan literatür taramasında demografik faktörler ve kişisel özelliklerin, üniversite öğrencilerinin girişimcilik eğilimlerini etkileyen önemli boyutlar arasında yer aldığı görülmüştür (Kristiansen ve Indarti, 2004; Linan ve Chen, 2009; akt. Karaçar, 2018: 607). Bu nedenle çalışma, geleceğin potansiyel girişimcileri olarak görülen üniversite öğrencilerinin girişimcilik eğilimlerinin güncel ve kapsamlı araştırmalara konu olarak tartışılması gerektiği düşüncesinden hareketle yapılmıştır.

Araştırma, bölgeler arasında gelişmişlik farklarının giderilmesinde önemli araçlardan biri olan girişimcilik eğilimi ile geleceğin potansiyel girişimci adayları olarak görülen üniversite öğrencilerinin demografik özellikleri arasındaki ilişkinin tespit edilmesi amacıyla üniversite öğrencilerinin demografik özellikleri ile girişimcilik eğilimleri arasında bir ilişki var mıdır sorusuna cevap aramaktadır. Araştırmanın örneklem büyüklüğünün 2000'in üzerinde olması, bir üniversitedeki fakültelerin çoğunun karşılaştırmalı olarak incelenmesi ve kalkınmada öncelikle bölgelerden biri olan Güneydoğu Anadolu Bölgesi, Diyarbakır ilinde yapılması çalışmayı farklı kılan unsurlar arasında sayılabilir.

\section{Literatür Taraması}

\subsection{Girişimcilik ve Girişimcilik Eğilimi}

Girişimcilikle ilgili ilk fikirler 18. yüzyılda Cantillon tarafından ifade edilmiştir. Konu ile ilgili araştırma yapan yazarlar tarafından girişimcilik oldukça farklı şekillerde tanımlanmıştır. Yıllar süren araştırmalar sonucunda tek bir tanım üzerinde anlaşmaya varılamamıştır. Son yıllarda üzerinde çalışılan moda bir terim olan girişimcilik genellikle kesin bir tanım olmadan kullanılmakta ve girişimcilikle ilgili farklı kriterlerin nasıl kullanılacağı tam manada açıklığa kavuşturulamamıştır (Iversen vd., 2008). Girişimciliği yeni unsurların bir araya getirilmesi ile farklı şeyler meydana getirmek şeklinde tanımlayan Schumpeter, bu durumun ekonomik kalkınmanın temelini oluşturduğunu iddia etmiş, ayrıca yeni şeyler oluşturan unsurları, yeni pazarların bulunması, yeni organize olma biçimlerinin oluşturulması, yeni üretim metotlarının geliştirilmesi, yeni ürün ya da hizmetlerin üretilmesi şeklinde sıralamıştır (Schumpeter, 1934). 
Müftüoğlu'na (2000) göre çevrenin sürekli takip edilmesi sonucu yeni fırsatları yakalama, talepteki değişimleri zamanında fark etme, yeni talepler oluşturma, kaynak temin ederek üretim tesisleri kurma girişimciliktir. Ayrıca rekabeti seven ve varlıklarının sebebi olarak gören, risk almaktan ve sorumluluktan çekinmeyen, atak ve yaratıcı kimselerde girişimcilerdir. Gürdoğan (2010) ise girişimcileri sınırları olmayan bir dünyada etkili ve güçlü ordulara benzetmekte, ürün ve hizmetleri ile toplumları değiştiren girişimcileri günümüz dünyasının simyacıları olarak ifade etmektedir.

Girişimcilik eğilimi ise kişinin yeni bir girişimde bulunurken gösterdiği yatkınlığını ve çocukluktan yetişkinliğe kadar kişinin gelişmesini etkileyen tüm etmenleri ifade eder. Bu eğilimin doğuştan kazanılmış olduğu düşünülse de geliştirilmesi ve yönlendirilmesi gereklidir (Ulama, 2016). Girişimcilik eğilimi, kişilerin kendi işlerini kurmalarına yönelik sahip oldukları arzu, istek ve gayretin ifadesidir. Özetle kişinin girişimcilik yapabilme kabiliyetiyle ilişkili bir kavram olarak ele alınmaktadır (Güreşçi, 2014). Girişimcilik eğilimi, bireysel ve çevresel faktörlerin birleşimidir. Kişilerin kendi işini kurma konusundaki isteğini ve kararlılığını ifade etmekte ve fırsatları görebilen ve toplum için değer yaratan, kendine güven ve başarma isteği olan, kişisel yetenekleri ile bir işe girişme niyeti olarak tanımlanabilir (Damar, 2015; Karaçar, 2018: 607).

Girişimcilik eğiliminin oluşumunda farklı bir takım faktörler yer almaktadır. Bu faktörler bireyin doğuştan sahip olduğu özellikler olmasa da bir takım yollarla tespit edilebilir, geliştirilebilir ve doğru şekilde yönlendirilebilir (Karakulle ve Karakaya, 2017: 599). Yapılan çalışmalar girişimcilik eğilimlerini etkileyen faktörler arasında demografik faktörler, kişisel özellikler ve çevresel faktörler olmak üzere üç temel kategori bulunduğunu göstermektedir (Franco vd., 2010; Kristiansen ve Indarti, 2004). Ayrıca girişimcilik eğiliminin oluşumunda toplumsal olarak geçmişten gelen girişimcilik birikiminin, kişinin yaşadığı sosyo-kültürel çevrenin, ailenin sahip olduğu özellik ve niteliklerin, kişinin çalışma yaşamıyla ilgili olarak örnek aldığı çevrenin ve genel toplumsal algının, ülkenin girişimcilik üzerine sahip olduğu teşvik ve yönlendirmelerin ve eğitim düzeyinin önemli etkisinin olduğu söylenebilir (Güreş̧̧i, 2014: 27). Kişisel faktörler ile çevresel faktörlerin girişimcilik eğiliminin gelişiminde birbirini tamamlayan iki etken olduğu söylenebilir (Salik ve Kaygın, 2016: 147).

Girişimcilik eğilimi, kişinin sahip olduğu niteliklerin çevresel faktörlerle geliştirilerek ülkenin ekonomik, sosyal ve kültürel gelişimine katkı sağlayacak bir unsurdur. Sahip olunan girişimci sayısının ve girişimcilerin toplamda ortaya koydukları katma değerin bölgesel düzeyden küresel düzeye taşınabilmesinin, ülkelerin gelişmişlik düzeylerinin belirlenmesinde önemli birer etken olduğu görülmektedir. Girişimcilik eğiliminin gelişiminde çevresel ve kişisel faktörlerin yanında üniversitelerinde yadsınamaz ve kritik rolleri bulunmaktadır. Günümüzde iş hayatına ve mesleğe yeni atılacak genç girişimci adayları olarak görülen üniversite öğrencilerinin sahip oldukları yeterlilik ve yetkinliklerin geliştirilmesinde birçok üniversite aktif rol oynamaktadır (Çetin, 2007; Karakulle ve Karakaya, 2017: 600).

\subsection{Girişimcilik ve Girişimcilik Eğilimi Araştırmaları}

Chen ve arkadaşlarına (1998: 301) göre girişimcinin kendi işini kurması ve işletmesi ile ilgili girişimcilik kararı birçok faktörden etkilenen karmaşık bir süreçtir. Bu faktörler, durumsal faktörler ve bireysel faktörler olmak üzere iki grup halinde ele alınmaktadır. İ̧̧ değiştirme, görevden alınma veya önceki iş deneyimleri durumsal faktörü, başarı ihtiyaçları ve kontrolü ele alma gibi faktörler bireysel faktörleri oluşturmaktadır. Ayrıca girişimcilik eğilimleri eğitim, aile, kültür, sosyal çevre, teknolojik çevre faktörlerine bağlı olarak değişiklik gösterebilmektedir.

Girişimcilik eğilimleri gerek araştırmacılar gerekse özel ve kamu sektörü taraflarınca teşvik gören, ciddi ve bütüncül bir çalışma olarak ele alınması gereken bir konu olarak tartışımıştır. Özellikle az gelişmiş ülkelerde, ekonomik gelişmeyi tetikleyici bir rol oynayan girişimci davranışlarının cesaretlendirilmesi oldukça önemli görülmektedir (Mueller ve Thomas, 2000).

Girişimci bireylerin varlığı sosyal, kültürel, ekonomik, demografik ve kişisel faktörlere bağlı olduğu kadar girişimciliğe olan istek ve eğilimlerine de bağlıdır. Bu noktadan hareketle girişimcilik, kârlı fırsatların varlığı ve girişimci bireylerin varlığı olmak üzere iki unsur arasındaki bağ olarak ifade edilebilir (Shane ve Venkatraman, 2000). 
Maddi bağımsızlık kazanma isteği girişimciliği tercih etme nedenlerinin başında gelmektedir. Bu durumun temelinde girişimciliğin gelir elde etme aracı olarak görülmesi yatmaktadır. Girişimci, mevcut sermaye ve sosyal statü bakımından bağımsız, kendi isteklerine göre hareket etmekte, karar alınırken ve uygulanırken başkalarından emir almamakta, başarı ve başarısızlığı başkalarıyla paylaşmamakta, kimseye rapor vermemekte ve sadece kendi potansiyelini gerçekleştirmektedir. Bu durum girişimciliği cazip bir özgürleşme aracına dönüştürmektedir (Keskin ve Zehir, 2002).

Üniversite öğrencilerine yönelik yapılan girişimcilik çalışmaları incelendiğinde yapılan bazı araştırmalar şöyle özetlenebilir:

Çukurova Üniversitesinde yapmış olduğu çalışmada Avşar (2007) öğrencilerin girişimcilik eğilimlerinin orta düzeyde olduğunu tespit etmiştir. İktisadi ve İdari Bilimler Fakültesi öğrencilerinin girişimcilik eğilimleri ortalamasının üniversite ortalamasının üzerinde, tıp ve mühendislik fakültesi öğrencilerinin ortalamaya yakın, eğitim fakültesi öğrencilerinin ortalamadan daha aşağı seviyede oldukları sonucuna ulaşmıştır. Aynı çalışmada demografik değişkenlerin girişimcilik eğilimi üzerinde etkisin olduğu tespit edilmiştir. Erkeklerin risk alma eğilimlerinin kadınlardan daha yüksek düzeyde olduğu, gelir düzeyi yüksek olanların yaratıcılık özelliğinin daha yüksek olduğu sonucu elde edilmiştir (Kılıç vd., 2012: 427).

Doğaner ve Altunoğlu (2010) işletme bölümü öğrencilerine yönelik yapmış oldukları çalışmada erkek öğrencilerin girişimcilik eğilimlerinin kız öğrencilerin girişimcilik eğilimlerinden daha fazla olduğu sonucunu elde etmişlerdir.

Kafkas ve Kırıkkale Üniversitesi öğrencilerinin girişimcilik eğilimlerini araştıran İşcan ve Kaygın (2011), öğrencilerin kendine güven, başarma ihtiyacı, kontrol odağına sahip olma ve risk alma, yenilik ve belirsizliğe karşı tolerans gibi kişilik özelliklerinin başarı düzeylerini ölçmüşlerdir. Çalışmanın sonunda bu kişilik özelliklerinin daha yüksek bir orana ulaşması için öğrencilere gereken desteğin verilmesinin önemi vurgulanmıştır.

Kılıç ve arkadaşları (2012) üniversite öğrencileri üzerinde yapmış oldukları çalışmada girişimcilik eğilimi ile cinsiyet arasında anlamlı sonuçlar elde etmişlerdir. Erkek öğrencilerin kız öğrencilere oranla daha girişimci oldukları sonucuna ulaşmışlardır.

Uluyol, (2013) girişimcilik dersi alan ve almayan öğrenciler üzerinde yapmış olduğu araştırmada Meslek Yüksekokulu öğrencilerinin girişimcilik eğilimlerinin yüksek düzeyde olduğu ancak girişimcilik ve finansal yönetim dersi alan ve almayan öğrencilerin girişimcilik eğilimleri arasında anlamlı bir farklılık olmadığı sonucuna varmıştır.

Yapılan çalışmalarda girişimcilik eğilimlerini etkileyen olumsuz koşullar arasında; eğitim eksikliği, finansman problemler, teknolojik yetersizlik, iş gücü yetersizliği, araştırma ve geliştirme süreci bilgisizliği; kişisel yeteneklerin zayıf olması ve psikolojik faktörler yer aldığı görülmüştür (Tiftik ve Zincirkıran, 2014: 183).

Üniversite öğrencilerine yönelik yapılan araştırmalara bakıldığında girişimcilik eğilimlerinin genellikle sosyodemografik özellikler (yaş, cinsiyet, eğitim düzeyi, gelir düzeyi vb.) ya da bireysel değerler gibi unsurlarla karşılaştırılarak ele alındığı görülmektedir. Araştırmalarda farklı türde ölçekler kullanılmakta olup sonuçları birbiriyle örtüşen çalışmaların yanı sıra farklı sonuçlar bulgulayan araştırmalar da mevcuttur (Arslan, 2002; Cansız, 2007; Çarıkçı ve Koyuncu, 2010; Yıldız ve Kapu, 2012; Akçakanat vd., 2014; Özdemir, 2015; Türkmen ve İşbilir, 2015).

\section{Yöntem}

\subsection{Araştırmanın Amacı}

Araştırma kapsamında girişimciliği özendirmek ve sürdürülebilir bir ekonomik büyüme sürecinde iş kurma kabiliyetine sahip genç girişimcilere duyulan ihtiyaca dikkat çekmek için Dicle Üniversitesinin farklı fakültelerinde eğitim gören öğrencilerin demografik özellikleri ile girişimcilik eğilimleri arasındaki ilişki düzeyini ortaya koymak amaçlanmıştır. Ayrıca çalışmanın amaçlarından biri de üniversite öğrencilerinin girişimcilik eğilimi düzeyini belirlemektir. 


\subsection{Veri Toplama Yöntemi}

Araştırmada kullanılan ölçek ilk olarak, üniversite düzeyindeki öğrencilerin girişimci özelliklerini tespit etmek amacıyla Yılmaz ve Sünbül (2009) tarafından geliştirilmiş ve birçok araştırmada kullanılmıştır (Bilge ve Bal, 2012; Kılıç vd., 2012; Aksel ve Bağcı, 2016; Aydeniz ve Akkuş, 2017; Soysal vd., 2017; Duman, 2018). 36 ifadeden oluşan ve Likert tipinde hazırlanan ölçekte ifadeler "çok sık" (5)'den "hiçbir zaman" (1)'e uzanan 5'li aralıklı ölçek formunda düzenlenmiştir. Ölçeğin Cronbach Alfa güvenilirlik değeri 0,93 bulunmuştur. Bu sonuç ölçeğin güvenilirlik düzeyinin çok yüksek olduğunu göstermektedir.

\subsection{Verilerin Analizi}

Yüz yüze anket yöntemiyle toplanan veriler SPSS 18.0 paket programı aracılığıyla frekans, ANOVA ve t-testi analizleri yapılarak değerlendirilmiştir.

\section{Bulgular}

Katılımcıların demografik özellikleri ile girişimcilik eğilimleri arasındaki ilişkileri tespit etmek üzere ttest ve ANOVA testleri yapılmıştır.

Katılımcıların girişimcilik eğilimleri ile cinsiyet değişkeni arasındaki ilişkiyi incelemek maksadıyla tTesti yapılmıştır. Test sonuçları Tablo 1'de gösterilmiştir.

Tablo 1. Cinsiyet Değiş̧eni ile Girişimcilik Arasındaki Iliş̧ki Analizi

\begin{tabular}{|c|c|c|c|c|c|c|}
\hline Cinsiyet & $\mathbf{n}$ & Ort. & SS & $\mathbf{t}$ & sd & p \\
\cline { 1 - 5 } Kadın & 1135 & 3,60 & 0,59 & $-1,06$ & \multirow{2}{*}{2295,79} & \multirow{2}{*}{0,289} \\
\cline { 1 - 5 } Erkek & 1163 & 3,63 & 0,60 & $-1,06$ & & \\
\hline
\end{tabular}

Tablo 1'e göre katılımcıların girişimcilik eğilimleri ile cinsiyet değişkeni arasındaki ilişkiyi incelemek için yapılan analiz sonucunda cinsiyet değişkeni ile girişimcilik eğilimi arasında (0,05 önem seviyesinde) anlamlı bir farklılaşma tespit edilememiştir. Ayrıca erkeklerin girişimcilik eğilimleri ile kadınların girişimcilik eğilimleri ortalamalarının erkekler lehine daha yüksek olduğu görülse de ortalama farkının çok fazla olmadığı görülmüştür.

Katılımcıların girişimcilik eğilimleri ile yaş değişkeni arasındaki ilişkiyi incelemek maksadıyla ANOVA testi yapılmıştır. Yaş aralıkları TUiK yaş grubu aralıkları baz alınarak belirlenmiştir (TUiK, 2018). Test sonuçları Tablo 2'de gösterilmiştir.

Tablo 2. Yaş Değişkeni ile Girişimcilik Arasındaki illişki Analizi

\begin{tabular}{|l|c|c|c|c|c|c|c|}
\hline & & & & & \multicolumn{3}{|c|}{ Tamhane's T2 } \\
\hline Grup & $\mathbf{n}$ & Ort. & SS & p & $\mathbf{1 6 - 1 9}$ & $\mathbf{2 0 - 2 4}$ & $\mathbf{2 5 - 2 9}$ \\
\hline $16-19$ Yaş & 327 & 3,53 & 0,66 & & & & \\
\hline 20-24 Yaş & 1566 & 3,66 & 0,57 & \multirow{2}{*}{$<0,001$} & 0,007 & & \\
\cline { 1 - 5 } 25-29 Yaş & 336 & 3,55 & 0,59 & & & 0,023 & \\
\hline 30 ve Üzeri Yaş & 70 & 3,44 & 0,72 & & & & \\
\hline
\end{tabular}

Tablo 2'de görüldüğü üzere göre yaş grupları ile girişimcilik arasında anlamlı bir ilişki bulunmaktadır. Homojenlik testi (Levene Statistic) sonucu varyansın homojen olmadığı tespit edilmiştir. Bu nedenle ilişkinin hangi ikili gruptan kaynaklandığını tespit etmek amacıyla Tamhane's T2 testi yapılmışır. Elde edilen sonuçlara göre 20-24 yaş grubunda olanlar ile $16-19$ ve 25-29 yaş grupları arasında olanlar arasında anlamlı bir farklılık olduğu görülmektedir. Diğer gruplar arasındaki farklııkların ise rastlantısal olduğu söylenebilir. Sonuç olarak 
20-24 yaş grubundakilerin girişimcilik eğilimlerinin diğer yaş gruplarından daha fazla etkin olduğu görülmektedir. Ancak yapılan testle ilgili kategoriler arasında sağlıklı bir karşılaştırma yapabilmek için kategorilerin eşit ya da eşite yakın dağılması gerektiği varsayımı çalışmanın kısıtları arasında yer almaktadır.

Katılımcıların girişimcilik eğilimleri ile eğitim gördükleri fakülteler arasındaki ilişkiyi tespit etmek üzere ANOVA testi yapılmıştır. Test sonuçları Tablo 3'te gösterilmiştir.

Tablo 3. Fakülte Değişkeni ile Girişimcilik Arasındaki İlişki Analizi

\begin{tabular}{|c|c|c|c|c|c|c|c|c|c|c|c|c|c|}
\hline & & & & & & & & Tamh & רane's T2 & & & & \\
\hline Fakülte & $n$ & Ort & SS & $p$ & 1 & 2 & 3 & 4 & 5 & 6 & 7 & 8 & 9 \\
\hline $\begin{array}{l}\text { İktisadi ve Idari } \\
\text { Bilimler (1) }\end{array}$ & 409 & 3,48 & 0,59 & \multirow{10}{*}{$<0,001$} & & & & & & & & & \\
\hline Edebiyat (2) & 319 & 3,53 & 0,68 & & & & & & & & & & \\
\hline Mimarlık (3) & 280 & 3,77 & 0,57 & & $<0,001$ & $<0,001$ & & & & & & & \\
\hline Mühendislik (4) & 101 & 3,78 & 0,50 & & $<0,001$ & 0,005 & & & & & & & \\
\hline Veterinerlik (5) & 198 & 3,81 & 0,51 & & $<0,001$ & $<0,001$ & & & & & & & \\
\hline Ziraat (6) & 188 & 3,48 & 0,63 & & & & $<0,001$ & 0,001 & $<0,001$ & & & & \\
\hline ilahiyat (7) & 255 & 3,58 & 0,50 & & & & 0,002 & & $<0,001$ & & & & \\
\hline Fen Bilimleri (8) & 80 & 3,63 & 0,65 & & & & & & & & & & \\
\hline Hukuk (9) & 90 & 3,69 & 0,56 & & & & & & & & & & \\
\hline Eğitim (10) & 379 & 3,64 & 0,57 & & 0,005 & & & & 0,021 & & & & \\
\hline
\end{tabular}

Tablo 3'te görüldüğg̈ üzere katılımcıların eğitim gördükleri fakülte değişkeni ile girişimcilik eğilimleri arasında anlamlı bir ilişki tespit edilmiştir. Yapılan homojenlik testi (Levene Statistic) sonucunda varyansın heterojen olduğu tespit edilmiştir. Bu nedenle gruplar arasındaki farklııı̆ın hangi ikili gruptan kaynaklandığını tespit etmek maksadıyla Tamhane's T2 testi yapılmıştır. İktisadi ve İdari Bilimler ile Mimarlık, Mühendislik, Veterinerlik ve Eğitim Fakülteleri arasında, Edebiyat fakültesi ile Mimarlık, Mühendislik ve Veterinerlik Fakülteleri arasında, Mimarlık Fakültesi ile Ziraat ve Illahiyat Fakülteleri arasında, Mühendislik Fakültesi ile Ziraat Fakültesi arasında, Veterinerlik Fakültesi ile Ziraat, Ilahiyat ve Eğitim Fakülteleri arasında istatistiksel olarak anlamlı farklııklar bulunmuştur.

Fakülteler düzeyinde girişimcilik ortalamaları en yüksek olanlar Mühendislik, Mimarlık ve Veterinerlik Fakülteleri öğrencileriyken, en düşük olanlar ise İktisadi ve İdari Bilimler ile Ziraat Fakülteleri öğrencileridir.

Katılımcıların girişimcilik eğilimleri ile sınıf değişkeni arasındaki ilişkiyi tespit etmek üzere ANOVA testi yapılmıştır. Test sonuçları Tablo 4'te gösterilmiştir.

Tablo 4. Sınıf Değişkeni ile Girişimcilik Arasındaki ilişki Analizi

\begin{tabular}{|c|c|c|c|c|c|c|c|}
\hline & & & & & \multicolumn{3}{|c|}{ Tamhane's T2 } \\
\hline Grup & $\mathbf{n}$ & Ort. & SS & p & 1.Sinıf & 2.Sinıf & 3.Sinıf \\
\hline 1. Sinıf & 514 & 3,55 & 0,63 & & & & \\
\hline 2. Sinıf & 648 & 3,58 & 0,62 & \multirow{2}{*}{$<0,001$} & & & \\
\hline 3. Sinıf & 543 & 3,63 & 0,56 & & & & \\
\hline 4. Sinıf & 594 & 3,70 & 0,54 & & $<0,001$ & 0,001 & \\
\hline
\end{tabular}

Tablo 4'te görüldüğü üzere katılımcıların eğitim gördükleri sınıf ile girişimcilik eğilimleri arasında anlamlı bir ilişki tespit edilmiştir. Yapılan homojenlik testi (Levene Statistic) sonucunda varyansın heterojen olduğu tespit edilmiştir. Bu nedenle gruplar arasındaki farklılı̆ın hangi ikili gruptan kaynaklandığını tespit etmek maksadıyla Tamhane's T2 testi yapılmıştır. 4. sınıf öğrencilerinin girişimcilik eğilimleri ile 1 ve 2 . sınıf 
öğrencilerinin girişimcilik eğilimleri arasında istatistiksel olarak anlamlı bir farklılık tespit edilmiştir. 4. sınıf öğrencilerin ortalamasının diğerlerinden daha yüksek olduğu tespit edilmiştir.

\section{Sonuç ve Tartışma}

Bir kamu üniversitesinin farklı fakültelerinde lisans eğitimi alan öğrencilerin, girişimcilik eğilimlerine ilişkin yapılan bu araştırmada, girişimcilik eğilimi ile demografik faktörlerden yaş, fakülte ve sınıf değişkenleri arasında anlamlı ilişkiler olduğu görülmüştür. Cinsiyet değişkeni ile girişimcilik eğilimi arasında anlamlı bir ilişki tespit edilememiştir. Çalışmaya benzer şekilde Bilge ve Bal (2012) araştırmaları sonucu cinsiyet değişkeninin girişimcilik üzerinde anlamlı bir etkisinin olmadığını belirtmiş̧ir. Wang ve Wong (2004) ise tam aksine cinsiyetin girişimciliğe etki ettiğini ifade etmiştir. Bazı çalışmalara benzer olacak şekilde araştırmada, erkeklerin girişimcilik ortalamalarının kadınlardan yüksek olduğu görülmüştür (Konaklıoğlu ve Kızanlıklı, 2011; Kılıç vd., 2012; Aksel ve Bağcı, 2016). Türkiye'de girişimciliğin istenilen düzeyde artmamasının temel sebeplerinden birisi kadınların iş piyasasında olması gereken yeri alamamasıdır. Dolayısıyla kadının çalışma hayatına katılımının yetersizliği genel girişimci sayısını düşürmektedir (KKA, 2018). Bu sonuçlara göre özellikle kadın girişimciliğinin (pozitif ayrımcılık yapılarak) gerek ülke genelinde gerekse Güneydoğu Anadolu bölgesi genelinde özendirilmesi gerektiği düşünülmektedir.

Öğrencilerin yaşları ile girişimcilik eğilimleri arasında anlamlı ilişkiler bulunmuştur. 20-24 yaş grubundaki öğrencilerin girişimcilik eğilimlerinin diğer yaş grubundaki öğrencilerden yüksek olduğu tespit edilmiştir. Mirza ve Dağdeviren (2016) yaptıkları araştırmada öğrencilerin girişimcilik özellikleri ile yaş ve cinsiyet değişkenleri arasında anlamlı bir ilişki olmadığını belirtmiştir. Aksel ve Bağcı (2016) ise girişimcilik ortalamalarının en yüksek olduğu yaş aralığını 24-26 yaş olarak tespit etmiştir.

Öğrencilerin eğitim gördükleri fakülte ile girişimcilik eğilimleri arasında anlamlı ilişkiler bulunmuştur. Mühendislik, Mimarlık ve Veterinerlik fakülteleri öğrencilerinin girişimcilik eğilimlerinin diğer fakülte öğrencilerinin girişimcilik eğilimlerinden yüksek olduğu tespit edilmiştir. Bu sonuca göre özellikle girişimcilik eğitimi alan İktisadi ve İdari Bilimler öğrencilerinin farkındalık düzeylerinin artırılması gerektiği söylenebilir. Ayrıca öğrenim görülen fakülteler incelenirken öğrencilerin girişimcilik eğilimlerinde saptanan farklılı̆ın sebeplerinin bölüm, kültürel çevre, üniversite yapısı gibi farklı değişkenler dikkate alınarak araştırılmasında fayda olacağı düşünülmektedir.

Elde edilen bir başka sonuca göre 4. sınıf öğrencilerin girişimcilik eğilimlerinin diğer sınıf öğrencilerin girişimcilik eğilimlerinden daha fazla olduğu tespit edilmiştir. Öğrencilerin almış oldukları eğitimin onların girişimcilik eğilimleri üzerinde etkisi olduğu söylenebilir. Ders, konferans vb. eğitim faaliyetleriyle girişimcilik eğilimlerinin artırılmasının ayrıca girişimcilerle öğrencilerin buluşacağı organizasyonların düzenlenerek öğrenciler açısından farkındalık oluşturulmasının faydalı olacağı söylenebilir.

Sonuç olarak, üniversite öğrencilerinin girişimcilik eğilimlerinin demografik değişkenler açısından incelendiği bu çalışmada demografik değişkenlerin öğrencilerin girişimcilik eğilimleri üzerinde önemli bir etkisinin olduğu ifade edilebilir. Bununla birlikte, konu ile ilgili farklı ölçekler kullanarak, öğrencilerin girişimcilik özellikleri ve eğilimleri, demografik özellikler, aile, sosyo-ekonomik çevre, kültürel çevre vb. farkı değişkenler açısından değerlendirilebilir. Araştırma sonuçları yapılması muhtemel diğer kamu üniversitesi araştırma sonuçlarıyla karşılaştırılırsa daha etkin sonuçlar ortaya çıkabilir.

\section{Kaynaklar}

Akçakanat, T., Mücevher, M. H., \& Çarıkçı, í. H. (2014). Sözel, sayısal ve eşit ağıllık bölümlerinde okuyan üniversite öğrencilerinin girişimcilik eğilimlerinin bazı demografik değişkenler açısından incelenmesi: SDÜ örneği. AKÜ iiBF Dergisi, 16(2), 137-153.

Aksel, İ., \& Bağcı, Z. (2016). Girişimcilik eğilimi: Bir kamu üniversitesinin IiBF’sinde öğrenim gören son sınıf öğrencilerinde bir araştırma. Insan ve Toplum Bilimleri Araştırma Dergisi, 7(5), 2120-2133.

Arslan, K. (2002). Üniversiteli gençlerde mesleki tercihler ve girişimcilik eğilimleri. Doğuş Üniversitesi Dergisi, 3(2), 1-11. 
Avşar, M. (2007). Yükseköğretimde öğrencilerin girişimcilik eğilimlerinin araştırılması, Çukurova Üniversitesinde bir uygulama. Çukurova Üniversitesi Sosyal Bilimler Enstitüsü, Yayımlanmamış Yüksek Lisans Tezi, Adana.

Aydeniz, N., \& Akkuş, B. (2017). Üniversite öğrencilerinin girişimcilik eğilimlerinin belirlenmesine yönelik bir araştırma: Munzur Üniversitesi örneği. Dicle Üniversitesi İktisadi ve İdari Bilimler Fakültesi Dergisi, 7(13), 162-177.

Bilge, H., \& Bal, V. (2012). Girişimcilik eğilimi: Celal Bayar Üniversitesi öğrencileri üzerine bir araştırma. Süleyman Demirel Üniversitesi Sosyal Bilimler Enstitüsü Dergisi, 2(16), 131-148.

Cansız, E. (2007). Üniversite öğrencilerinin girişimcilik özelliklerinin belirlenmesi: Süleyman Demirel Üniversitesi öğrencileri üzerine bir çalışma. Süleyman Demirel Üniversitesi Sosyal Bilimler Enstitüsü, Doktora Tezi, Isparta.

Chen, C. C., Grene, G. P., \& Crick, A. (1998). Does entrepreneurial self-efficacy distingush entrepreneurs from managers? Journal of Business Venturing, 13, 295-316.

Çarıkçı, i. H., \& Koyuncu, O. (2010). Bireyci-toplumcu kültür ve girişimcilik eğilimi arasındaki ilişkiyi belirlemeye yönelik bir araştırma. Mehmet Akif Ersoy Üniversitesi Sosyal Bilimler Enstitüsü Dergisi, (3), 1-18.

Çetin, M. (2007). Bölgesel kalkınma ve girişimci üniversiteler. Ege Akademik Bakış, 7(1), 217-238.

Damar, A. (2015). Girişimci kişilik özelliklerinin öğrencilerin girişimcilik eğilimlerine etkisi: Sannio Üniversitesi ve Selçuk Üniversitesi'nde karşılaştırmalı bir araştırma. Selçuk Üniversitesi Sosyal Bilimler Enstitüsü Yüksek Lisans Tezi, Konya.

Doğaner, M., \& Altunoğlu, A. E. (2010). Adnan Menderes Üniversitesi Nazilli İktisadi Ve İdari Bilimler Fakültesi İşletme Bölümü öğrencilerinin girişimcilik eğilimleri. Organizasyon ve Yönetim Bilimleri Dergisi, 2(2), 103-110.

Duman, B. (2018). the relationship between the entrepreneurship characteristics and metacognitive awareness levels of pre-service teachers. Journal of Education and Training Studies, 6(5), 152-159.

Franco, M., Haase, H., \& Lautenschlager, A. (2010). Students' intrepreneurial intentions: An inter-regional comparison. Education and Training, 52(4), 260-275.

Gürdoğan, N. (2010). Girişim ve girişimcilik kültürü. İstanbul: İgiad Yayınları.

Güreşçi, E. (2014). Girişimcilik eğilimi üzerine bir araştırma: İspir Hamza Polat Meslek Yüksekokulu örneği. Girişimcilik ve Kalkınma Dergisi, 9(1), 23-38.

Iversen, J., Jorgensen, R., \& Malchow-Moller, N. (2008). Defining and measuring entrepreneurship. Now Publishers Inc.

İşcan, Ö., \& Kaygın, F. (2011). Potansiyel girişimciler olarak üniversite öğrencilerinin girişimcilik eğilimlerini belirlemeye yönelik bir araştırma. Organizasyon ve Yönetim Bilimleri Dergisi, 12(2), 275-286.

Karaçar, E. (2018). Turizm lisans öğrencilerinin girişimcilik eğilimleri - Sinop Üniversitesi örneği, Journal of Tourism and Gastronomy Studies, 6(2), 602-621.

Karakulle, İ., \& Karakaya, A. (2017). Üniversite öğrencilerinin girişimcilik eğilimleri üzerine bir araştırma. The Journal of Academic Social Science, 5(46), 596-614.

Keskin H. A., \& Zehir, L. (2002). Girişimcilik hisleriyle girişimcilik potansiyeli arasındaki ilişki: Gebze ve civarındaki girişimciler üzerine bir saha araştırması. Doğu Akdeniz Üniversitesi 21.Yüzyılda KOBi’ler: Sorunlar, Fırsatlar ve Çözüm Önerileri Sempozyumu.

Kılıç, R., Keklik, B., \& Çalış, N. (2012). Üniversite öğrencilerinin girişimcilik eğilimleri üzerine bir araştırma: Bandırma iiBF İşletme Bölümü örneği. Süleyman Demirel Üniversitesi İktisadi ve İdari Bilimler Fakültesi Dergisi, 17(2), 423-435.

KKA, (2018). Karacadağ Kalkınma Ajansı istihdam ve işgücü piyasası raporu, Diyarbakır.

Konaklığlu, E., \& Kızanlıklı, M. M. (2011). Üniversite öğrencilerinin proaktif kişilik özellikleri ile girişimcilik eğilimleri arasındaki ilişki. Ticaret ve Turizm Eğitim Fakültesi Dergisi, 1(2), 72-92.

KOSGEB, (2018). Yatırım teşvik uygulamalarında bölgeler. http://www.kosgeb.gov.tr /Erişim Tarihi: 30.07.2018)

Kristiansen, S., \& Indarti, N. (2004). Entrepreneurial intention among Indonesian and Norwegian students. Journal of Enterprising Culture, 12(1), 55-78.

Linan, F., \& Chen, Y. W. (2009). Development and cross-cultural application of a specific instrument to measure entrepreneurial intentions. Entrepreneurship Theory and Practice, 33(3), 119-144.

Mirza, Ş., \& Dağdeviren, i. E. (2016). Meslek yüksekokulu öğrencilerinin girişimcilik eğilimlerinin belirlenmesine yönelik Eşme Meslek Yüksekokulunda bir araştırma. Uşak Üniversitesi Sosyal Bilimler Dergisi, 9(5), 82-105.

Mueller, S. L., \& Thomas, A. S. (2000). Culture and entrepreneurial potential: A nine country study of locus of control and innovativeness. Journal of Business Venturing, 16(1), 51-75.

Müftüoğlu, T. (2000). Kobi ve girişimcilik. KOSGEB Sanayicinin Sesi, Aralık, (1), 10-11. 
Özdemir, L. (2015). Kırgızistan-Türkiye Manas Üniversitesi öğrencilerinin girişimcilik eğilimlerinin sosyo-demografik özellikler açısından değerlendirilmesi. Süleyman Demirel Üniversitesi İktisadi ve İdari Bilimler Fakültesi Dergisi, 20(1), 41-65.

Salik, N., \& Kaygın, E. (2016). Demografik değişkenler açısından üniversite öğrencilerinin girişimcilik eğilimlerinin belirlenmesi: Kafkas Üniversitesi örneği. Kahramanmaraş Sütçü İmam Üniversitesi Sosyal Bilimler Dergisi, 13(1), 145-162.

Schumpeter, J. (1934). The theory of economic development. Cambridge, MA: Harvard University Press.

Shane, S., \& Venkatraman, S. (2000). The promise of entrepreneurship as a field of research. Academy of Management Review, 25(1), 217-226.

Soysal, A., Kıran, Ş., \& Salmi, H. (2017). Sağlık yönetimi bölümü lisans öğrencilerinin girişimcilik eğilimleri ve özelliklerinin bazi sosyo-demografik özellikler açısından incelenmesi. International Journal of Academic Value Studies, 3(14), 48-59.

Tiftik, H., \& Zincirkiran, M. (2014). A survey of entrepreneurial tendencies candidate young entrepreneurs: Foundation University sample. Journal of Management Research, 6(2), 177-200.

TUik, (2018). IIl, yaş grubu ve cinsiyete göre nüfus, 2007-2017. http://www.tuik.gov.tr/PrelstatistikTablo.do?istab_id=945 (Erişim Tarihi: 30.07.2018)

Türkmen, M., \& İşbilir, U. (2015). Üniversite öğrencilerinin girişimcilik eğilimlerinin sosyo-demografik özellikler açısından incelenmesi. CBÜ Beden Eğitimi ve Spor Bilimleri Dergisi, 9(2), 18-28.

Ulama, S. (2016). Turizm lisans öğrencilerinin girişimcilik eğilimleri üzerine bir araştırma: Sakarya Üniversitesi örneği. International Conference On Eurasian Economies.

Uluyol, O. (2013). Öğrencilerin girişimcilik eğilimlerinin belirlenmesi: Gölbaşı Meslek Yüksekokulu örneği. Adıyaman Üniversitesi Sosyal Bilimler Enstitüsü Dergisi, 6(15), 349-372.

Yıldız, S., \& Kapu, H. (2012). Üniversite öğrencilerinin bireysel değerleri ile girişimcilik eğilimleri arasındaki ilişki: Kafkas Üniversitesi'nde bir araştırma. KAÜ-iiBF Dergisi, 3(3), 39-66.

Yılmaz, E., \& Sünbül, A. M. (2009). Üniversite öğrencilerine yönelik girişimcilik ölçeğinin geliştirilmesi. Selçuk Üniversitesi Sosyal Bilimler Enstitüsü Dergisi, (21), 195-203.

Wang, C. K., \& Wong P. K. (2004). Entrepreneurial interest of university students in Singapore. Technovation 24(2), 163172. 
This Page Intentionally Left Blank 